\title{
The Influence of the Principal's Leadership Behavior and Islamic School Culture on Teacher's Performance
}

\author{
Rizki Ulfah*, Sururi \\ Educational administration \\ Universitas Pendidikan Indonesia \\ Bandung, Indonesia \\ *rizkiulfah117@upi.edu
}

\begin{abstract}
This research aims to understand the influence of leadership of the school principals and Islamic school culture of teacher's performance. The kind of research done is associative with the quantitative approach. Measurement techniques used is Likert scale. Analysis of the technique used is a technique analysis of the statistic parametric as the form of research is associative, with employing correlation bivariate data/product moment Pearson. This research did in Bandung, especially in Islamic Junior High Schools. In this research the samples are a head of school and teacher's with consisted of 60 people. In this research technique and an instrument, the collection of the data used by interviews and questionnaires. The result of this research is that there a correlation of relationship which is very strong between variables leadership the school principals and Islamic school culture with the performance of teacher's in Islamic Junior High Schools in Bandung.
\end{abstract}

Keywords-leadership, Islamic school culture, teacher performance

\section{INTRODUCTION}

Islamic junior high schools are essentially a schools that implementing the concept of Islamic education based on the Al-Quran and As Sunnah. The operational concept of Islamic junior high school is an accumulation of the process of civilization, inheritance and development of Islamic teachings, culture and Islamic civilization from generation to generation.

The Islamic schools as junior secondary education providers that are dedicated to producing outstanding graduates and have a good character. This can be achieved if it is supported by teachers who meet academic qualifications and have high competence, as well as teachers who have good morals who can be role models, because teachers are one of the essential components in a National Education System. The roles, duties and responsibilities of teachers are very meaningful in realizing the functions and purpose of education. To realize the functions and purpose of the education, competent and qualified teachers are needed so that they can carry out roles, duties, responsibilities as with a highly strategic position in helping students, of course a professional teacher or in other words has a high performance. The teacher's ability to understand the situation of students can be influenced by various factors, internal and external factors

Basically, performance can be seen from two directions, which is individual performance (teachers) and organizational performance (schools). A Teacher's performance is the demonstration of teacher's behavior of organizational performance. Meanwhile, organizational performance is the totality of the work achieved by an organization. Because teacher performance describes the level of achievement of task implementation in an organization, in an effort to realize the goals, objectives, vision and mission of the organization, while organizational performance is closely related to the performance of teachers, organizations or schools that have high-performance individuals who will have high competitiveness. Conversely, if the individuals in the organization have poor performance, the organization's competitiveness will be weak.

In the Republic of Indonesia Law Number 2 of 1989 clearly stated the purpose of Educational National, that is to educate the nation's life and develop a complete human being the faithful and faithful God Almighty, virtuous, has knowledge and skills, having physical and spiritual health, a personality steady and independent and a sense of responsibility society and nationality. On the other side in the realization of national education goal's there are still many problems in education.

One of the problems facing the nation Indonesia is still quality education classified as low, especially basic elementary and medium. Education will be achieved if the components are found within improving the quality of education meet certain requirements. Component that plays a part in improved education is one of them is the quality educators that are able to address challenges Quickly and responsibly. As described in the RI Law Number 14 of 2005, teachers are educator's professionals with the main task of educating, teach, guide, direct, train, assess, and evaluate learners on early childhood education pathway education formal, basic education, and education medium. The teacher is responsible directly with the formation of the character of the participant's students through development and improvement personality as well as instil moral values desired and it must start from education 
elementary school level therefore elementary teachers must has good performance and discipline.

Teachers must be good role models for students. To increase the quality and effectiveness of teaching teachers, many factors that influence it, including is the principal's leadership, because the principal is a person who plays a role important in regulating the learning process activities.

Teaching and the principal are also responsible answer directly with the implementation of all kinds and the form of regulations or rules that must be implemented both by teachers and students. According to Robbins leadership is the ability to motivate employees, organize other individual activities, choose the most effective communication channel, or resolve conflicts among its members [1].

Teacher's performance is seen not only influenced by the leadership of the principal but also what is the role of a head schools can create a school culture this can improve teacher performance. Teacher performance is a culture seen as something more dynamic, not a rigid and static one. Teacher performance is expected to boost the quality and the relevance of education, in its implementation in The field depends on many factors influence and are interrelated, for example, the leadership factor of the principal and school culture. In improving the quality of education also influenced by work habits, culture work, and mutually organizational cultures related. Without work culture and culture organizations that lead to a work culture quality, then the quality improvement efforts optimally will not be achieved as which are expected.

Theoretically this research later is expected to: (1) Enrich the repertoire Science; (2) Material for further study for future researchers; and (3) The results of this study are expected used as a contribution of information for other parties either directly or indirectly who are attracted to the influence of leadership and school culture with work discipline. In practical terms, the results of this study are later are expected to: (1) Make donations useful thoughts for Education in Bandung with a purpose fix and take steps broader, policies, deep coaching order to improve leadership relationships and school culture with teacher performance for future; (2) increase leadership and managing the school culture to improve teacher performance; and (3) as an input in improving teacher performance.

\section{METHODS}

The nature of the problem will be researched, then this research uses quantitative, descriptive, with a correlation research design. Based from this type of research, this research classified as correlational research because this study aims to determine the direction and size the relationship of the variables studied. Correlation research is a research that involves the act of collecting data use determine if there is a relationship and level the relationship between two or more variables. Sudjana suggest that "the level of the relationship between the two variables is indicated by the coefficient correlation (r) [2]. The correlation coefficient will be large if the relationship level is high and must be small if the level of the relationship is small or weak.

The correlation coefficient must qualify that condition the correlation coefficient should be free of that units used to measure variables both predictors and responses. Correlation technique it's used to analyse relationships between two free variables (free variable) which is the leadership of the principal (X1) and school culture (X2) with one free, namely teacher performance (Y). The population in this study is a sample of teachers at Islamic junior high schools in Bandung.

In this research for collecting data used the questionnaire method. This study uses a Likert scale used consists of five alternative options answers 1 to 5 are modified to a scale attitude with the following performance: always, often, sometimes, rarely, never. The range of ideal scores is according to a Likert scale ranges from 1 to 5 because there are five alternative answers.

Before the instrument was used for testing needs to be tested for validity first and reliability. Research instruments that have been compiled first tested for now its validity and reliability to respondents who are not included in the sample as many as 30 teachers in 30 Islamic-based junior high schools in Bandung. From the results of the validity test note that: a leadership instrument principal, number of valid items is 30 out of 35 items. Cultural instruments school, the number of valid items is 29 of the 35 items. 6 questions that were otherwise not valid. Teacher performance instruments, number of items valid 30 out of 35 items. 5 items are declared invalid.

The SPSS output results regarding the test instrument reliability is: leadership the principal amounted to 0.898. All test results reliability of the three variables can categorized as very high reliable and can concluded that $\mathrm{rh}>\mathrm{rt}(0.361)$. Through a frame of mind and foundation existing theory, then the hypothesis in research it can be assumed that: (1) there is a relationship between leadership (X1) and improvement teacher performance $(\mathrm{Y})$; (2) there is a relationship between school culture $(\mathrm{X} 2)$ with increased performance teacher $(\mathrm{Y})$; and (3) there is a relationship between styles leadership (X1) and School Culture (X2) with an increase in teacher performance (Y).

\section{RESULTS AND DISCUSSION}

\section{A. Results}

1) Descriptive analysis: Based on the results of calculations against The score for the principal's leadership style shows that the maximum score is 146 and a minimum score of 108 with a mean of 128.21. Based on the results of calculations against the score of school culture variables obtained data that the maximum score is 140 and a score minimum of 107 with a mean of 125.38 . And the results of the calculation of the score teacher performance variables obtained data that score a maximum of 147 and a minimum score equal to 104 with a mean of 127.6 . 
2) Research requirements test: Residual data normality test results principal leadership, school culture and teacher performance by using Kolmogorov-Smirnov showed that all three residuals were normally distributed. In addition, test results heteroscedasticity indicates that the variable principal leadership with variables teacher performance and school culture variables with the teacher performance variable being homogeneous seen from the distribution of standardized residual values does not form a certain pattern but is visible random can be said that the regression model is homogeneous or does not contain heterokedassitas. Before doing the test correlation between variables, it is necessary to do data linearity test. Linearity test of the relationship between the principal's leadership and teacher performance indicates the significance value of the deviation of linearity of $0.274>0.05$ which means that the relationship between head leadership schools where teacher performance is linear. Test The linearity of the relationship between school cultures with teacher performance showing value The significance of the deviation of linearity is $0.296>0.05$ which means that the relationship between school culture with teacher performance linear. And the last is the independence test to test whether the two independent variables (between X1 and X2) are independent or not. Result the calculation of the independence test between variables free (between X1 and X2) is the Result between the independent variables $\mathrm{X} 1$ and $\mathrm{X} 2$ in regression model. (calculation results on attachment).

\section{B. Discussion}

1) Correlation between principal leadership and teacher's performance: The results of this research are in accordance with those stated by experts on leadership, as stated by Rivai [3], leadership is a process influence in determining the organization, motivate follower behavior to achieve purpose, influence to improve group and culture. Badeni states that leadership is ability, process and the art of influence people and groups of people in order to have willingness to achieve the porpose organizational [4]. Various studies have also proven that the leader factor plays an important role in organizational development. Factor a very important leader is character of the person who became the leader.

In this research it is known that there is a correlation between principal leadership relationship schools with teacher performance of $64.2 \%$. Principal leadership relationship with teacher performance shows the results of the regression coefficient positive and significant. Headmaster has a heavy responsibility as leaders in his school with regard to management of human resources, namely teachers which he leads. This means that if principal leadership is good, then teacher performance will also increase.

This result according to the theory or opinion of Ministry of Education and culture in Primary School Management 1995 explains that "Educational leadership is the principal's ability to deliver influences that can cause teachers are moved to achieve educational goals efficiently and effectively. " Therefore good leadership of the Principal and effective in leading the organization in this is Primary School in Lubuklinggau city then teacher performance is increasing. This matter proven by the results of the regression analysis that principal leadership coefficient positive sign.

2) School cultural relations (X2) with teacher's performance $(Y)$ : The development of school culture can be implemented with the development of aspects of harmony, order, spirit and spirit, and management total quality. A good school culture will effectively produce the best performance on each individual, work group / unit and school as an institution, and relationships synergy between the three levels.

In research that has been conducted by researchers can say that there is the relationship between school culture and teacher performance $46.9 \%$, which means that the principal leadership is $64.2 \%$ more dominant compared to school culture. The relationship between school culture and teacher performance shows the results of the positive regression coefficient and significant.

A positive school culture will encourage all school members to work together based on mutual trust, invite participation of all citizens, encouraging the emergence of new ideas, and giving opportunity for the implementation of updates at school which it all comes down to achieving the best results. The school culture good can improve school performance, either the principal, as well as the teacher. The situation will materialize when the cultural qualifications it is healthy, solid, strong, positive, and professional. Positive school culture can improve teacher performance in carry out their professional duties expected to improve school quality, performance in school and the expected quality of life have healthy, dynamic or active, positive characteristics and professional.

Thus it can be concluded that a positive school culture can provides an opportunity for an idea can improve teacher performance and help creation of quality schools. Every school resident must be able to adjust on the existing school culture. With the development of a good school culture will can grow the spirit that will be improve teacher performance in running task, so as to improve quality the school. This is evidenced by the results regression analysis that the coefficient of leadership the principal is positive.

3) The relationship between principal's leadership (X1) and school culture (X2) with teacher performance (Y): Based on the results of the regression analysis multiple regression equation line is obtained namely $\mathrm{Y}=13,938+0.697 \mathrm{X} 1+$ $0.194 \mathrm{X} 2$. This result shows a positive sign according to theory and can be interpreted as leadership principal and good school culture then the teacher's performance will be good too. The regression equation results can be also interpreted as follows: (1) constant Signed positive indicates the second if there is no independent variable, the teacher's performance 
amounting to 13,938 . (2) if the variable is leadership the principal increased by one point by 0.697 assuming the school culture variable.

\section{CONCLUSION}

Based on research results and the discussion above can be concluded that there is a positive relationship between leadership principal and teacher's performance in Islamic junior high school in Bandung. Meanwhile, the conclusion in particular is as follows: (1) there is a positive relationship between principal leadership with performance teachers of Islamic junior high school in Bandung. This shows that principal leadership increases or good then the teacher's performance will also increase, means there is a direct relationship between principal leadership with teacher performance. (2) There is a positive relationship between cultures schools and teacher performance of Islamic junior high school in Bandung. This shows that the school culture increase or good then the teacher's performance will also increase, it means there is a relationship directly between school culture and teacher's performance; (3) There is a positive and significant relationship principal leadership and culture school with teacher performance, this identifies that the better principal leadership and culture school then teacher performance will also increase.

\section{REFERENCES}

[1] S.P. Robbins, Perilaku Organisasi. Jakarta: Indeks Kelompok Gramedia. Thoha, Miftah. 2006. Perilaku Organisasi Konsep Dasar Dan Aplikasinya. Jakarta: Raja Grafindo Persada, 2006.

[2] D. Sudjana, Pengantar Manajemen Pendidikan Luar Sekolah, 1992.

[3] V. Rivai and D. Mulyadi, Kepemimpinan dan Perilaku Organisasi, Edisi Ketiga. Jakarta: PT Raja Grafindo Persada, 2006

[4] M.A. Badeni, Kepemimpinan dan Perilaku Organisasi. Bandung: CV. Alfabeta, 2013 